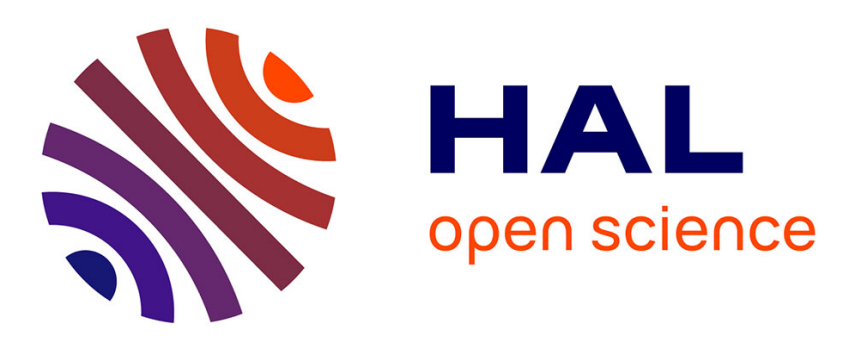

\title{
d -Serine as a Key Building Block: Enzymatic Process Development and Smart Applications within the Cascade Enzymatic Concept
}

Nazim Ocal, Mélanie L'enfant, Franck Charmantray, Loredano Pollegioni, Juliette Martin, Pascal Auffray, Jérôme Collin, Laurence Hecquet

\section{To cite this version:}

Nazim Ocal, Mélanie L'enfant, Franck Charmantray, Loredano Pollegioni, Juliette Martin, et al.. d -Serine as a Key Building Block: Enzymatic Process Development and Smart Applications within the Cascade Enzymatic Concept. Organic Process Research and Development, 2020, 24 (5), pp.769-775. 10.1021/acs.oprd.0c00024 . hal-02995483

\section{HAL Id: hal-02995483 https://hal.science/hal-02995483}

Submitted on 9 Nov 2020

HAL is a multi-disciplinary open access archive for the deposit and dissemination of scientific research documents, whether they are published or not. The documents may come from teaching and research institutions in France or abroad, or from public or private research centers.
L'archive ouverte pluridisciplinaire HAL, est destinée au dépôt et à la diffusion de documents scientifiques de niveau recherche, publiés ou non, émanant des établissements d'enseignement et de recherche français ou étrangers, des laboratoires publics ou privés. 


\title{
D-Serine as a Key Building-Block : Enzymatic
}

\section{Process Development \& Smart Applications within}

\section{Cascade Enzymatic Concept}

\author{
Nazim Ocal, $\uparrow$ Mélanie L'enfant, $\uparrow$ Franck Charmantray, $\uparrow$ Loredano Pollegioni,, \\ Juliette Martin $\ddagger^{*}$, Pascal Auffraył, Jérôme Collin $\neq *$ Laurence Hecquet ${ }^{*} *$ \\ † Université Clermont Auvergne, CNRS, SIGMA Clermont, Institut de Chimie de Clermont- \\ Ferrand (ICCF) F-63000 Clermont-Ferrand (France) \\ † Protéus by Seqens, 70 Allée Graham Bell F-30035 Nîmes (France) \\ $\S$ Department of Biotechnology and Life Sciences, Università degli Studi dell'Insubria, Varese \\ (Italy) \\ KEYWORDS. D-Serine, D-Threonine Aldolase, D-Amino Acid Oxidase, Transketolase, Ketoses
}

\begin{abstract}
An efficient enzymatic way catalyzed by an enzyme from D-Threonine Aldolase family was developed for D-serine production at industrial scale. This process was applied to the synthesis of two valuable ketoses, L-erythrulose and D-fructose, within cascade enzymatic concept involving both other enzymes. Indeed, D-serine was used as a substrate of D-amino acid oxidase
\end{abstract}


for the in situ generation of the corresponding ketoacid, hydroxypyruvate, a key donor substrate of Transketolase. This enzyme catalyzed the irreversible transfer of the ketol group from hydroxypyruvate to an aldehyde acceptor to form a (3S)-ketose by stereoselective carbon-carbon bond formation. The compatibility of all enzymes and substrates allowed to develop a three step enzymatic process avoiding the purification of intermediates. This strategy was validated with two TK aldehyde substrates to finally obtain the corresponding (3S)-ketoses with a high control of the stereoselectivity and excellent aldehyde conversion rates.

\section{INTRODUCTION}

Small molecule drug candidates in the Pharmaceutical pipeline today are becoming more complex. The increasing complexity requires ever more sophisticated and selective processes, especially in the realm of asymmetric synthesis. The mild neutral conditions coupled with the high specificity and low relative cost inherent with the use of enzymes has led to an emergence of the use of biocatalysts in the synthesis of bulk chemicals and drug compounds.

Like chemocatalysts, biocatalysts are designed to perform highly selective and specific chemistry, but can be comprised of engineered enzymes. They have the advantage of being heavy-metal free, and thus do not require the removal of metal impurities after completion of a reaction. Consistent with the homochirality of biomolecules, the reactions catalyzed by enzymes generally exhibit high stereo- and regioselectivities, generating products highly enriched for single enantiomers. Additionally, biocatalysts are highly efficient, allowing catalysis to be performed under mild reaction conditions, with reduced energy consumption and greenhouse gas emissions in comparison to chemical catalysis. 
In addition to being used to replace chemocatalysts in straightforward asymmetric reactions, biocatalysis can sometimes be used to complete chiral transformations with significantly fewer steps. One such example with molecules harboring more than one of the same type of functional group: while chemocatalysis is often not selective for one specific of those group (thus requiring protection/deprotection steps), enzymes have the capability to selectively react with a single functional groups in a molecule, reducing the overall process steps, time and cost. There are also cases where enzymes are able to achieve transformations that cannot be performed effectively or at all using classical chemical methods or chemocatalysis. In many cases, biocatalysis can mediate complex transformations that generate complex intermediates or APIs with multiple chiral centers. Here, biocatalysis affords access to novel structures and can potentially have significant impacts on manufacturing time and cost.

Biocatalysts are extensively used in the industrial production of bulk chemicals and pharmaceuticals, and over 300 processes have already been implemented ${ }^{1}$. Moreover, in the past 10 years, the application of biocatalysis in API synthesis has become a method of choice in many industrial processes ${ }^{2}$. Initially the focus was on the application of hydrolytic enzymes (e.g., lipases, proteases, esterases) and biocatalysts for asymmetric reduction of ketones (e.g., alcohol dehydrogenases, ketoreductases). Recently the scope of biocatalysis has broadened significantly with new reaction platforms coming on stream ${ }^{3}$, including transaminases, oxidases, nitrilases, aldolases, and ammonia lyases. Increasingly biocatalysts are available commercially "off-theshelf' in forms that are readily adaptable to synthetic organic chemistry operations, which enable chemists to rapidly identify applications of enzymes using specific target intermediates of interest. To aid synthetic chemists in identifying where biocatalysts might be usefully applied, a recent publication highlighted the need for rules and guidelines ${ }^{4}$ for "biocatalytic retrosynthesis". The 
main objective of "biocatalytic retrosynthesis" is to encourage synthetic organic chemists to include consideration of biocatalytic step(s) when planning a synthetic route to a target molecule. This new approach will require a greater understanding by synthetic chemists regarding which possible transformations and suitable intermediates might be considered using biocatalysis, and importantly how they might impact the overall efficiency, sustainability, and safety of the final manufacturing process.

Approaches in synthetic route design, leading to some key building blocks within competitive process synthesis is essential for efficient use in mainly complex molecules synthesis. Moreover, enzymatic strategies have emerged as powerful approaches to the eco-friendly, highly selective synthesis of valuable chiral compounds. To compete with the productivity of traditional methods, the use of two or even more enzymes in cascade can considerably improve the efficiency of a multistage synthesis by obviating the isolation of intermediates, thus saving time, resources, reagents and energy, while reducing waste ${ }^{6-8}$. The best option is when cascade reactions can be performed using a one-pot strategy: to avoid limitations, such as substrate/product/reagent inhibition or incompatibility of reaction conditions ( $\mathrm{pH}$, temperature), a telescoped, sequential one-pot procedure can be used. ${ }^{6}$

In the area of chiral polyols, particularly monosaccharides and analogs, largely used in API, enzymatic reactions are particularly useful to generate assymmetric centers with high stereoselectivity, avoiding protection and deprotection steps required by the chemical ways. Beside enzymatic aldose-ketose isomerization, ${ }^{9}$ enzymes catalyzing a stereospecific C-C bond formation such as aldolases ${ }^{19}$ and transketolases are also popular. ${ }^{11}$ Transketolase, TK (EC 2.2.1.1), belonging to the thiamine diphosphate-dependent enzyme family, catalyzes a two-carbon chain elongation by transferring an $\alpha$-hydroxy carbonyl (ketol) group from a donor to an aldehyde 
acceptor, thereby producing the $\mathrm{C}_{\mathrm{n}+2}(3 S)$-ketose by the stereoselective formation of the C2-C3 bond. (Scheme 1) In nature, TK is involved in the pentose phosphate metabolic pathway where this enzyme transfers a ketol group to reversibly equilibrate ketoses and aldoses carrying a terminal phosphate ester group. Previous in vitro studies showed that non-phosphorylated substrates can also be used as TK substrates leading to the corresponding free ketoses in one step. Particularly, release of carbon dioxide from hydroxypyruvate (HPA) as donor confers a major advantage on the TK-catalyzed reaction by rendering the reaction irreversible, thus making TK a powerful tool for the asymmetric synthesis of ketoses and related acyloin compounds (Scheme 1). ${ }^{11}$

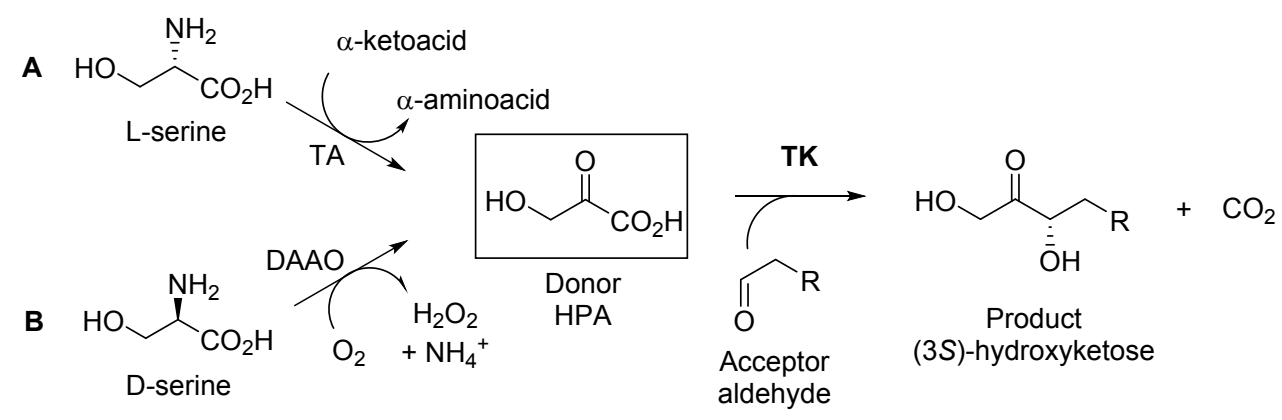

Scheme 1: In situ generation of HPA from TA or DAAO-catalyzed reaction coupled with TKcatalyzed reaction.

The main problem of the TK-catalyzed reaction for synthetic purposes conducted at industrialscale, is the HPA synthesis, which is commonly obtained by hydrolysis of toxic bromopyruvic acid in the presence lithium hydroxide, leading to a moderate yield. ${ }^{12}$ This compound is also commercially available but highly expensive. In addition, HPA is unstable in water at temperature $>25^{\circ} \mathrm{C} \cdot{ }^{13}$ To circumvent all these limitations, enzymatic in situ generation of HPA has been previously described, in particular from L-serine using transaminases (TA $)^{14}$ and more recently, from D-serine using D-amino acid oxidase (Scheme 1). ${ }^{15}$ This last way offers major advantages 
compared to TA strategy, such as an irreversible reaction and no requirement of an additional substrate.

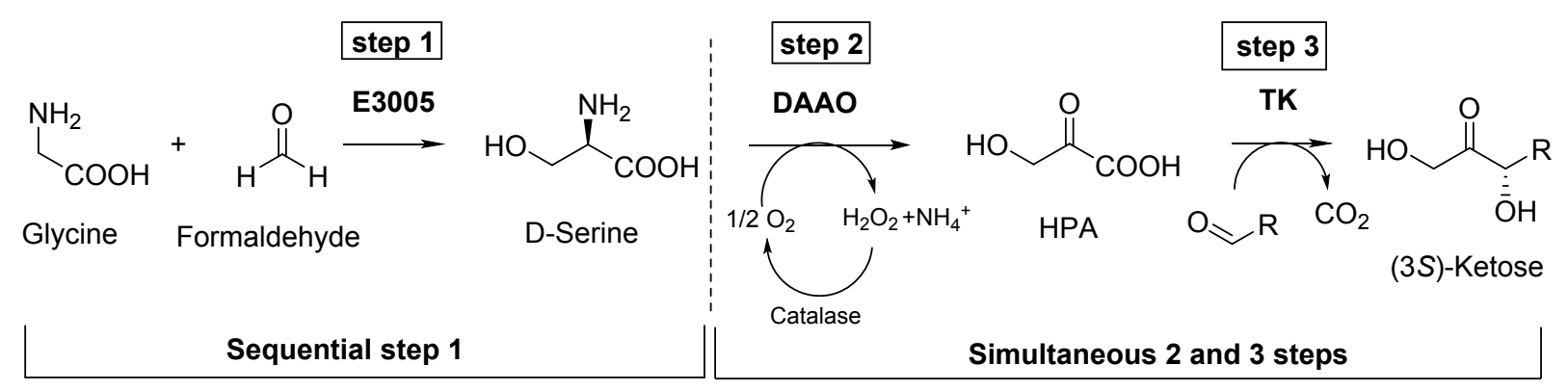

Scheme 2: One pot three-steps enzymatic cascade catalyzed by a crude extract of $E$. coli strain E3005 and purified D-amino acid oxidase from Rhodotorula gracilis $\left(\mathrm{DAAO}_{\mathrm{Rg}}\right)$ and transketolase from Geobacillus stearothermophilus $\left(\mathrm{TK}_{\mathrm{gst}}\right)$ with three different $\mathrm{TK}$ aldehyde substrates glycolaldehyde $\left(\mathrm{R}=-\mathrm{CH}_{2} \mathrm{OH}\right)$, D-glyceraldehyde $\left(\mathrm{R}=-\mathrm{CHOH}(R)-\mathrm{CH}_{2} \mathrm{OH}\right)$ and D-erythrose $(\mathrm{R}=$ $\left.-\mathrm{CHOH}(R)-\mathrm{CHOH}(R)-\mathrm{CH}_{2} \mathrm{OH}\right)$.

In this work, we first carried out a detailed investigation of D-serine production at industrial scale catalyzed by an enzyme from the D-Threonine Aldolases family (D-TA) overexpressed in Escherichia coli strain. This process was then applied in a sequential cascade enzymatic concept for the in situ generation of HPA from D-serine, allowing the efficient synthesis of two valuable $(3 S)$-ketoses (Scheme 2). In a first enzymatic step, D-serine, was produced from achiral compounds glycine and formaldehyde according a process developed at industrial scale by Sequens Company. Then, two simultaneous enzymatic steps were developed at laboratory scale. DAAO from Rhodotorula gracilis $\left(\mathrm{DAAO}_{\mathrm{Rg}}\right)$ transformed D-serine into the corresponding ketoacid, hydroxypyruvate ${ }^{16}$ used by TK from Geobacillus stearothermophilus $\left(\mathrm{TK}_{\mathrm{gst}}\right)^{13}$ in the presence of an aldehyde as acceptor for obtaining the ketose product. The one pot three steps process was validated using three TK aldehyde acceptors, glycolaldehyde, D-glyceraldehyde and 
D-erythrose for the synthesis of corresponding valuable $(3 S)$-ketoses, L-erythrulose, a tanning agent in the cosmetics industry, ${ }^{17}$ and D-fructose, a sweetener with very low glycemic index. ${ }^{18}$

\section{RESULTS AND DISCUSSION \\ D-serine Enzymatic Process Development}

In the one pot three steps cascade enzymatic concept, the first step was performed independently for the production of D-serine by the Escherichia coli strain E3005 (whole cells) and with glycine and formaldehyde as substrates. This strategy was developed by Seqens Company and applied to the production of D-serine in an enantiomerically pure form ( $>99 \%$ ee) at multiton scale per year. The corresponding biocatalyst, an enzyme (E3005) from the D-Threonine Aldolases family (DTA) was identified. The enzyme activity requires a cofactor generally pyridoxal-5-phosphate (PLP) and magnesium chloride $\left(\mathrm{MgCl}_{2}\right)$ to ensure the protein stability (Scheme 3).

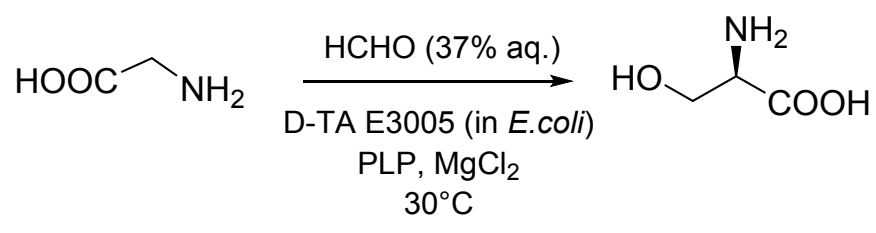

Scheme 3: Enzymatic aldolization of glycine with formaldehyde by biocatalyst D-TA expressed in $E$. coli $\mathrm{E} 3005$ for selectively producing D-serine.

The reaction is carried out in water with glycine (300g.L. $\left.\mathrm{L}^{-1}\right)$ and formaldehyde (37\% aq.) in presence of D-TA, produced by E. coli E3005 (10\% w/w). The $\mathrm{pH}$ is continuously controlled during the synthetic reaction step by adding $\mathrm{KOH}$. At the end of the reaction, the $\mathrm{pH}$ is decreased, the reaction mixture is then concentrated followed by the elimination of the whole cells. The crude D-serine product is treated with charcoal to remove the salts, filtered to remove any cell/protein residues followed by a recrystallization step in a water/alcohol mixture. The enzyme candidate 
was selected among our off-the-shelf enzymes portfolio ${ }^{19}$ which provided the required level of enantioselectivity ( $>99 \%$ ee). In this work, we describe the biotransformation process reactions conditions that were developed in order to ensure high performance, high productivity and robustness for multi-ton manufacturing. Among the different studied parameters, we have determined the optimal amounts of PLP, temperature, $\mathrm{pH}$ and glycine concentrations.

\begin{tabular}{ll}
\hline Parameters & Process Values \\
\hline $\mathrm{pH}$ & $7 \pm 0,5$ \\
$\mathrm{MgCl}_{2}$ & $0.003 \mathrm{eq}$ \\
$\mathrm{PLP}$ & $0.05 \% \mathrm{w} / \mathrm{w}$ \\
$\mathrm{Base}$ & $\mathrm{KOH} 35.7 \%$ \\
Temperature & $30^{\circ} \mathrm{C}$ \\
Conversion rate & $\sim 90 \%$ \\
of both substrates & $\sim 90$ \\
\hline
\end{tabular}

Table 1: Conditions for glycine and formaldehyde biotransformation into D-serine by whole cells expressing D-TA

$\underline{\text { PLP }}$

PLP is the cofactor required for full functioning of the enzyme during the reaction: its amount is determinant for an efficient cost effect. The best results were obtained within $0.05 \% \mathrm{w} / \mathrm{w}$ of PLP (chart 1). 


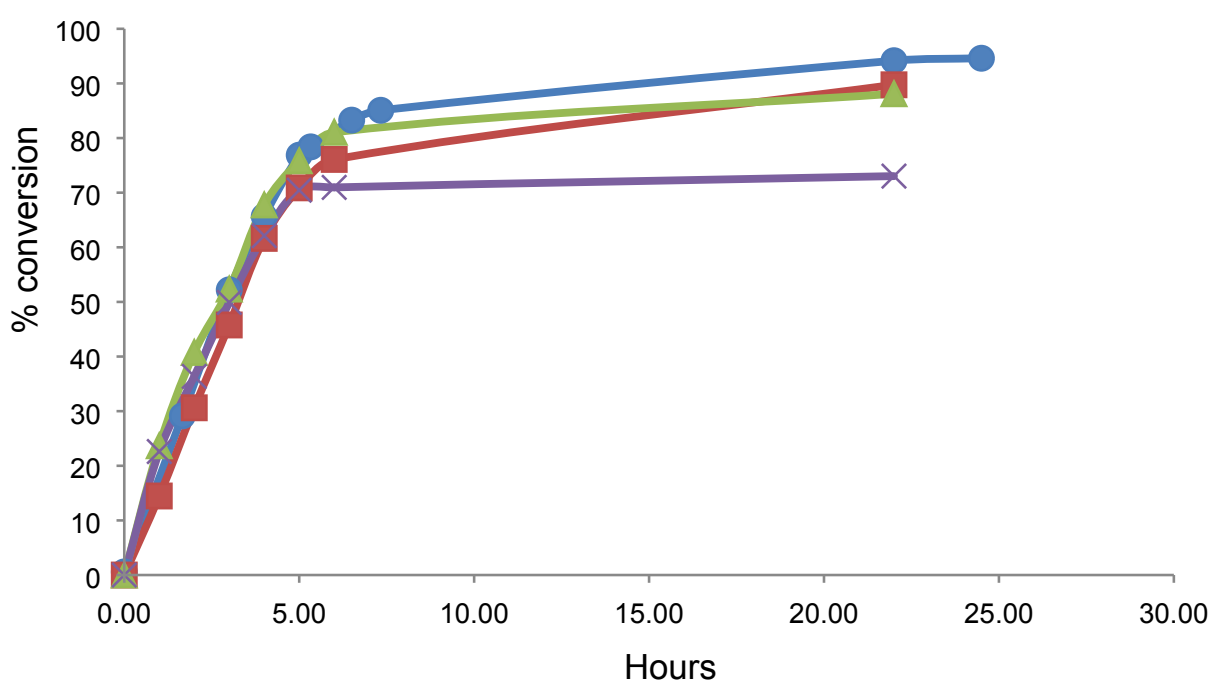

Chart 1. Influence of PLP concentration on conversion rate of glycine $\bullet 0.3 \% \mathrm{w} / \mathrm{w} ; \mathbf{\square} 0.1 \% \mathrm{w} / \mathrm{w}$; $\Delta 0.05 \% \mathrm{w} / \mathrm{w} ; \mathrm{X} 0.01 \% \mathrm{w} / \mathrm{w}$

\section{Temperature}

At temperature above $40^{\circ} \mathrm{C}$, the conversion rate is rapidly limited by the degradation of formaldehyde yielding inhibition of the enzymatic activity. Furthermore, significant amount of impurities was observed between 40 and $50^{\circ} \mathrm{C}$ (not shown). We therefore focused the operational temperature range between 25 and $35^{\circ} \mathrm{C}$ : the best conversion was observed at $30^{\circ} \mathrm{C}$ (Chart 2 ).

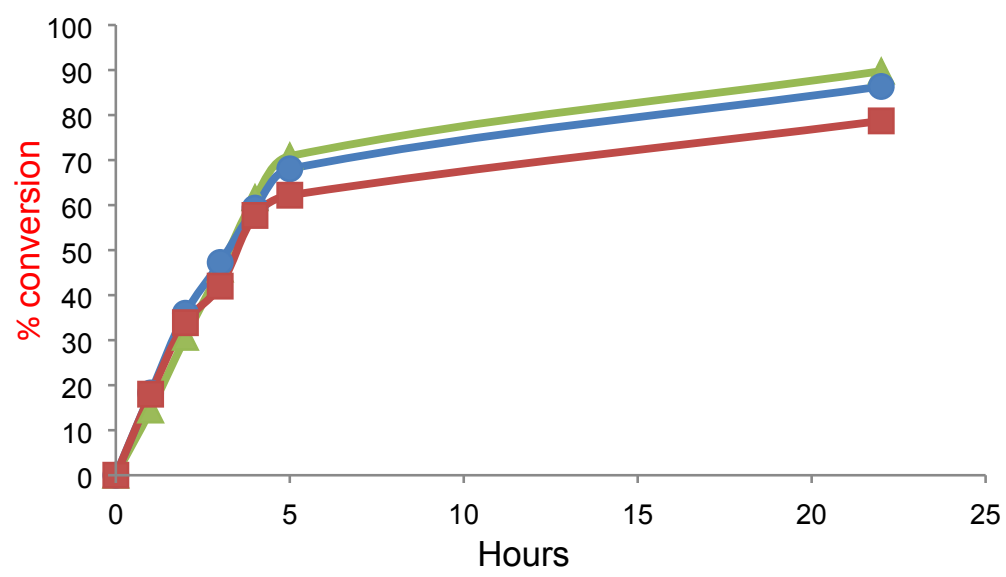

Chart 2: Influence of temperature on conversion rate of glycine $\Delta 35^{\circ} \mathrm{C} ; \bullet 30^{\circ} \mathrm{C} ; \boldsymbol{\square} 25^{\circ} \mathrm{C}$. 


\section{pH optimum and its control}

We have evaluated the effect of $\mathrm{pH}$ in the 6-8 range on the enantioselective conversion (Chart 3). The optimal activity was observed at $\mathrm{pH} 7$ - 7.5. The control of this $\mathrm{pH}$ range allows to ensure high conversion profile with limited impact on racemization, conducting to the formation of less than $1 \%$ formation of L-serine.

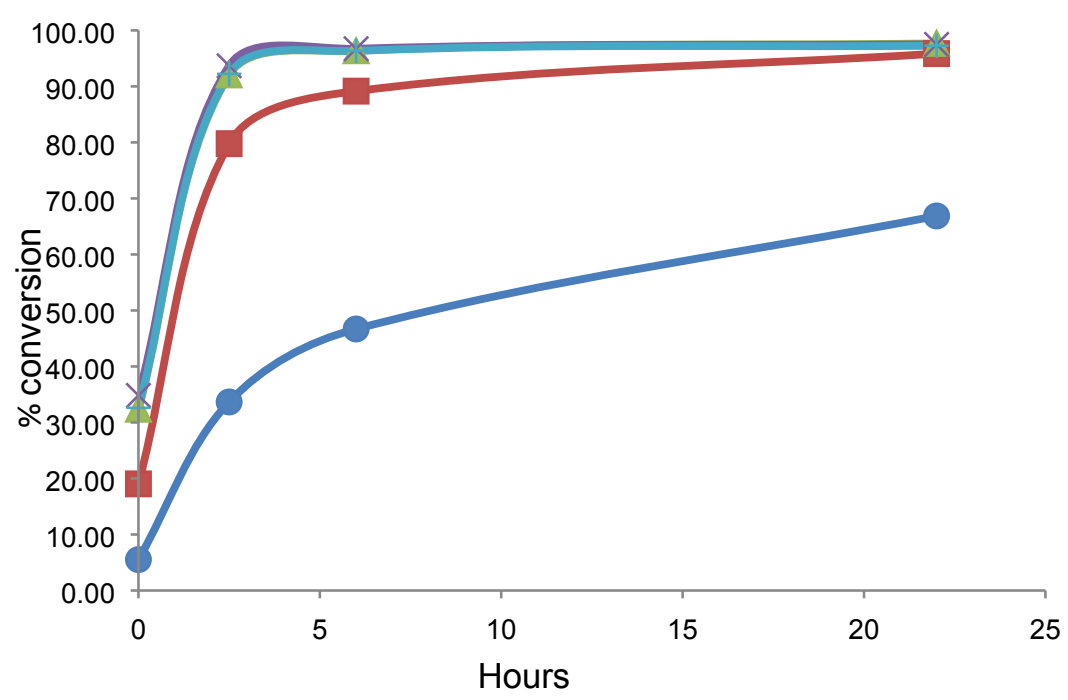

Chart 3: Influence of $\mathrm{pH}$ on conversion rate of glycine. • $1 \mathrm{~B} \mathrm{pH} 6$; $2 \mathrm{~B} \mathrm{pH} 6.5 ; \boldsymbol{\Delta} 3 \mathrm{~B} \mathrm{pH} 7 ; \mathrm{X}$ $4 \mathrm{~B} \mathrm{pH} 7.5 ;+5 \mathrm{~B} \mathrm{pH} 8$.

Nature of the base for $\mathrm{pH}$ control

During the reaction, the medium tends to acidify due to $\mathrm{HCHO}$ addition. Among the different studied bases, $\mathrm{NH}_{4} \mathrm{OH}$ and $\mathrm{KOH}$ were the best compounds to achieve full conversion into D-serine and avoiding potential racemization (Chart 4). The conversion in the presence of $\mathrm{KOH}$ (test F16514-05B) is significantly better, while the use of $\mathrm{NH}_{4} \mathrm{OH}$ allows a simple distillation step at the end of reaction. 


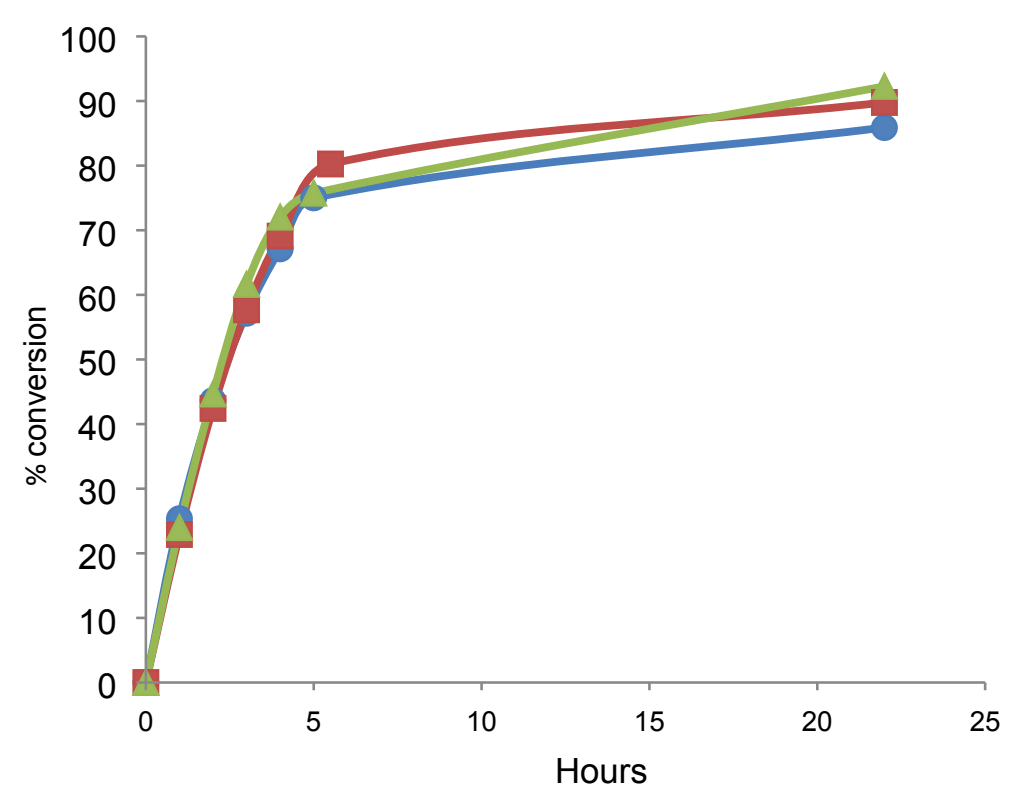

Chart 4: Influence of the nature of the base used to control $\mathrm{pH}$ on conversion rate of glycine. $\mathrm{NH}_{4} \mathrm{OH}-\mathrm{F} 16514-056$ - KOH 35.7\%-F16514-58 ; $\boldsymbol{\Delta} \mathrm{KHCO}_{3}-\mathrm{F} 16514-072$.

\section{$\underline{\text { Scale-up studies }}$}

At first, we developed the fermentation process of the D-TA enzyme overexpressed in Escherichia coli. To define the fermentation process, a Statistical Experimental Design has been carried out in order to determine the critical and important parameters, such as oxygen concentration, glucose feed and its optimal concentration, and other medium components impact. This approach allowed us to determine a robust domain of operations for producing the overexpressed enzyme. The Fermentation at different scales, from lab scale (2L) to several cubic meters volume fermenter size (up to $15 \mathrm{~m}^{3}$ ), have been implemented successively before ensuring production in large fermenters (Figure 4). 


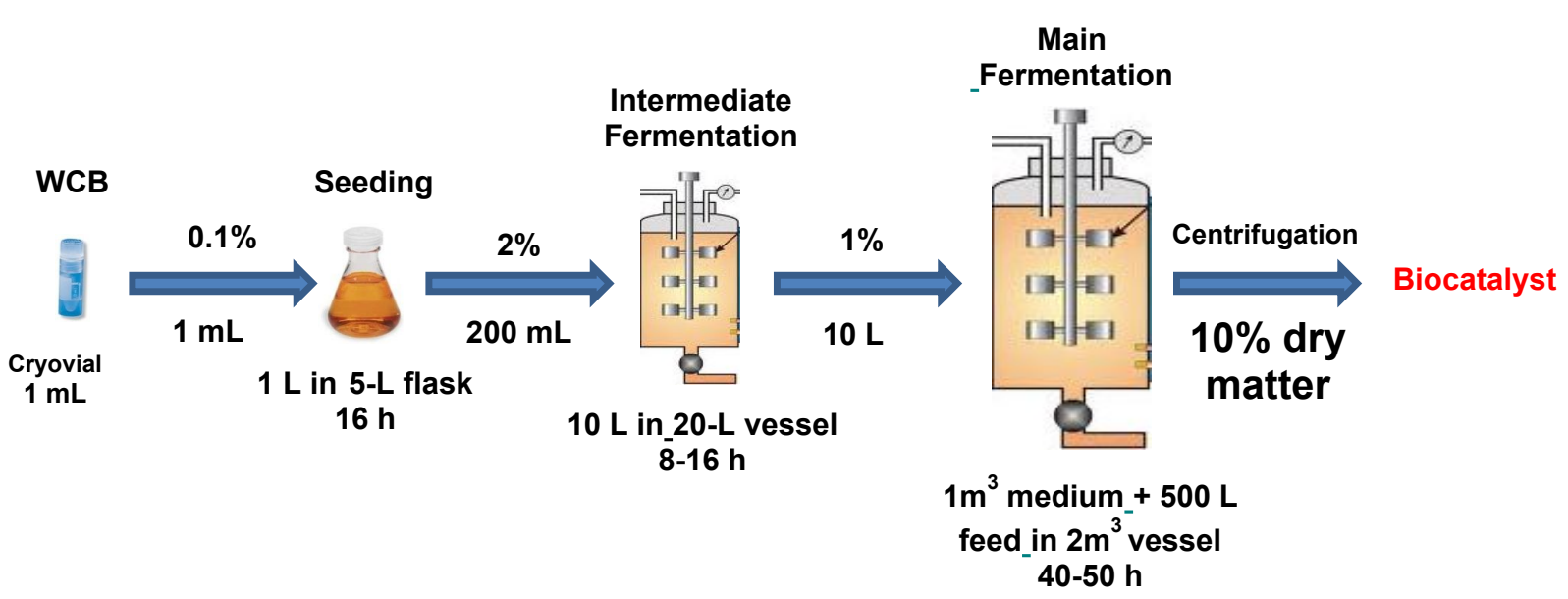

Figure 4: Different steps of fermentation process for biocatalyst production (D-TA enzyme overexpressed in Escherichia coli).

The obtained biocatalyst is represented by the E. coli E3005 wet biomass that is introduced into the biotransformation step. The corresponding heterogeneous mixture can lead to foaming issues. Indeed, control of foaming in bioprocesses at larger scale remains a dilemna, since a highly surface active heterogeneous system has to be adequately aerated and agitated while the bioreaction is proceeding without interruption. Special emphasis has been made by testing chemical antifoaming agents and to the determination of their efficiencies. The foam suppression or collapse is a result of a fine balance between the effects of various surface active agents. We have therefore investigated the efficiency at industrial scale correlating agitation turbulence and speed for ensuring full control on the conversion rate while maintaining high enantioselectivity. 
Once the reaction is stopped, the mixture is directly filtrated onto a filter press combined with a filtration adjuvant, such as diatomaceous earth, in order to avoid clogging issues.

\section{$\underline{\text { D-Serine isolation }}$}

The crude product is then recrystallized in a mixture of water and alcohol. Based on serine solubility profiles, ${ }^{20}$ we were able to determine the most appropriate isolation process in respect with the zwitterionic specie, within high yield recovery $(>70 \%)$. This process offers many advantages compared to the other microbial procedures ${ }^{21}$ such as asymmetric synthesis for full conversion of achiral, cheap and affordable substrates, no requirement of enzyme purification, high stereoselectivity of the enzyme-catalyzed reaction.

\section{Smart Application to ketose production within Cascade Enzymatic Concept}

The production of D-serine catalyzed by D-TA-E3005 cell free extract (CFE) ${ }^{\circ}$ was first studied in terms of substrate concentrations (Table 1).

Table 1. Influence of substrate concentrations on D-serine production.

\begin{tabular}{|c|c|c|c|c|}
\hline \multirow{2}{*}{$\begin{array}{l}\text { D-TA } \\
\text { cell free extract } \\
\text { (mg of proteins) }\end{array}$} & \multicolumn{2}{|c|}{ Substrates(mM) } & \multirow{2}{*}{$\begin{array}{l}\text { Reaction } \\
\text { time }(\mathrm{h})^{\circ}\end{array}$} & \multirow{2}{*}{$\begin{array}{l}\text { Glycine } \\
\text { conversion rate }(\%)^{\mathrm{a}}\end{array}$} \\
\hline & Glycine & Formaldehyde & & \\
\hline 3.5 & 50 & 50 & $24 \mathrm{~h}$ & 94 \\
\hline 3.5 & 100 & 100 & $24 \mathrm{~h}$ & 82.5 \\
\hline \multicolumn{5}{|c|}{ determined by in situ ${ }^{1} \mathrm{HNMR}$} \\
\hline \multicolumn{5}{|c|}{ The best results were obtained with glycine and formaldehyde at $50 \mathrm{mM}$ allowing an almost } \\
\hline
\end{tabular}


to precipitate CFE proteins to avoid by-products formation from substrates and reagents used in steps 2 and 3. After filtration and methanol evaporation, D-serine was used in the second part of the process in which both $\mathrm{DAAO}_{\mathrm{Rg}}$ and $\mathrm{TK}_{\mathrm{gst}}$ enzymes were coupled for the synthesis of the ketoses.

$\mathrm{DAAO}_{\mathrm{Rg}}$, overexpressed in $E$. coli and purified by $\mathrm{Ni}^{2+}$ chelating affinity column chromatography as reported earlier (SI), ${ }^{16}$ was used to convert D-serine into HPA. The choice of this enzyme can be explained by its broad amino acid spectrum including D-serine while the best substrates for LAAOs are hydrophobic amino acids. ${ }^{22}$ In addition, $\mathrm{DAAO}_{\mathrm{Rg}}$ showed much higher turnover number, better stability under a wide range of reaction conditions, and a larger active site to accommodate various substrates than the other source of DAAOs.24 ${ }^{23}$ DAAOs (EC 1.4.3.3) are flavin adenine dinucleotide (FAD)-containing flavoenzymes that catalyze the deamination of Damino acids to their imino acid counterparts with concomitant reduction of FAD which is subsequently re-oxidized by molecular oxygen with generation of hydrogen peroxide. The released imino acid spontaneously hydrolyses to the corresponding $\alpha$-keto acid and ammonia (Scheme 2). The thermostable $\mathrm{TK}_{\mathrm{gst}}$ was selected for its properties compatible with industrial applications such as high stability and robustness against unusual conditions, reusability after immobilisation ${ }^{24}$ and evolvability. ${ }^{25} \mathrm{TK}_{\mathrm{gst}}$ was overexpressed in E. coli and purified by $\mathrm{Ni}^{2+}$ chelating affinity column chromatography as reported earlier (SI). ${ }^{13}$

The two-step cascade reaction catalyzed by $\mathrm{DAAO}_{\mathrm{Rg}}$ and $\mathrm{TK}_{\mathrm{gst}}$ was performed using D-serine obtained with D-TA-3005 and an appropriated aldehyde as TK acceptor substrate. To validate the strategy, two aldehydes having an increased carbon chain length were chosen, such as glycolaldehyde $C_{2}(\mathbf{1})$, and D-erythrose $C_{4}(2)$ leading to the corresponding valuable $C_{n+2}$ ketoses, L-erythrulose $\mathrm{C}_{4}(\mathbf{3})$, and D-fructose $\mathrm{C}_{6}(\mathbf{4})$ respectively (Table 2 ). 
The influence of different concentrations of both enzymes and TK aldehyde substrates were first studied and the best conditions are indicated in table 2 .

Table 2. Conditions and results of one-pot cascade reactions for ketoses $\mathbf{3}$ and $\mathbf{4}$ synthesis from aldehydes $\mathbf{1}$ and $\mathbf{2}$ and $\mathrm{D}$-serine, obtained by coupling $\mathrm{DAAO}_{\mathrm{Rg}}$ and $\mathrm{TK}_{\mathrm{gst}}$

\begin{tabular}{|c|c|c|c|c|c|c|}
\hline $\begin{array}{l}\text { TK acceptors } \\
\text { Aldehydes }^{\mathrm{a}}\end{array}$ & $\begin{array}{l}\text { TK products } \\
\text { Ketoses }\end{array}$ & $\begin{array}{l}{ }_{\mathrm{DAAO}} \mathrm{Rg}_{\mathrm{Rg}} / \mathrm{TK}_{\mathrm{gst}} \\
(\mathrm{mg})^{\mathrm{a}}\end{array}$ & $\begin{array}{l}\text { Aldehyde } \\
\text { conversion } \\
\text { rate }(\%)^{b}\end{array}$ & $\begin{array}{l}\text { Reaction } \\
\text { Time } \\
(\mathrm{h})^{\mathrm{c}}\end{array}$ & $\begin{array}{l}\text { Isolated } \\
\text { product } \\
\text { yield }(\%)\end{array}$ & $\begin{array}{l}\text { e.e. or } \\
\text { d.e. } \\
(\%)^{\mathrm{d}}\end{array}$ \\
\hline ता & 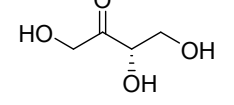 & $2 / 6$ & 82 & 8 & $60 \%$ & $>95 \%$ \\
\hline 1 & 3 & & & & & \\
\hline $\begin{array}{ll}\mathrm{O} & \mathrm{OH} \\
\mathbf{2} & \end{array}$ & $\begin{array}{l}\mathrm{HO} \\
4\end{array}$ & $2 / 6$ & $>95$ & 8 & $57 \%$ & $>95 \%$ \\
\hline
\end{tabular}

a Reactions were carried out with DAAO ${ }_{\mathrm{Rg}}(2 \mathrm{mg})$ and $\mathrm{TK}_{\mathrm{gst}}(6 \mathrm{mg})$, ThDP $(0.1 \mathrm{mM}), \mathrm{MgCl}_{2}(1$ $\mathrm{mM})$, aldose $(50 \mathrm{mM})$, D-serine $(50 \mathrm{mM})$ at $\mathrm{pH} 7$ and $25^{\circ} \mathrm{C}$. $^{\mathrm{b}}$ Alehyde acceptor conversion determined by in situ ${ }^{\mathrm{I}} \mathrm{H}$ NMR analysis. ${ }^{\mathrm{c}}{ }^{\mathrm{H}}$ NMR of reaction mixture (SI). ${ }^{\mathrm{d}}$ Enantiomeric excess (e.e.), diastereoisomeric excess (d.e.) determined by ${ }^{1} \mathrm{H}$ NMR.

For all reactions, the same concentration $(50 \mathrm{mM})$ of both substrates D-serine and aldehyde $\mathbf{1}$ or $\mathbf{2}$ was used. The ratio $\mathrm{DAAO}_{\mathrm{Rg}} / \mathrm{TK}_{\mathrm{gst}}$ was adjusted to obtain a total conversion of D-serine considering that a minimum amount of both enzymes was used and to avoid $\mathrm{DAAO}_{\mathrm{Rg}}$ inhibition by HPA. Hence, the bi-enzymatic cascade allowed an almost total $(82 \%$ and $95 \%$ for $\mathbf{1}$ and $\mathbf{2}$ respectively) and rapid ( $8 \mathrm{~h}$ ) conversion of both substrates as observed by in situ ${ }^{1} \mathrm{H}$ NMR (Table 2). Both ketoses were purified and characterized as the only products, with high enantio- and diastereoselectivity (> 95\%) and obtained with good isolated yields (57-60\%).

CONCLUSIONS 
An efficient enzymatic way catalyzed by D-TA overexpressed in Escherichia coli strain E3005 was developed in whole cells for D-serine production at industrial scale. A Smart Application of this D-TA catalyzed process was applied to ketose production within cascade enzymatic concept involving both other enzymes, DAAO and TK. The three enzymatic steps were performed with cell free extracts for the synthesis of two valuable (3S)-ketoses, L-erythrulose 3 and D-Fructose 4 with good yields and excellent stereoselectivities. This process allowed to resolve the major drawback of TK-catalyzed reaction for potential industrial applications. Indeed, HPA the key TK donor substrate rendering the reaction irreversible was in situ generated by D-TA and then DAAO from achiral glycine and formaldehyde.. This environmentally friendly procedure from affordable and cheap precursors represents an interesting alternative to the conventional chemical synthesis of HPA from toxic bromopyruvate and to the in situ HPA generation by reversible enzymatic Transaminase-catalyzed reaction from L-serine, requiring an additional $\alpha$-ketoacid as amino acceptor and an excess of one substrate to shift the equilibrium. Since the three enzymes are active under similar conditions, the multistep cascade synthesis obviated the isolation of intermediates, thus allowing to save time, resources, reagents and energy, while reducing waste.

The entire process could be further optimized, especially by co-immobilization of all enzymes to ensure their reusability and by performing the conversion in a continuous reactor for higher scale production of ketoses. The procedure could also be extended to TK variants or to other HPAdependent enzymes in place of wild-type TK for obtaining a wide range of $(3 S)$-ketoses and analogs.

\section{EXPERIMENTAL SECTION}


General. All chemicals were purchased from Sigma-Aldrich, Alfa-Aesar and CarboSynth. Bradford reagent was from Bio-Rad. Ni-NTA resine was obtained from QIAGEN. Proteins and enzymes were acquired from Sigma-Aldrich. Lyophilisation was carried out with Triad LABCONCO dryer. UV-visible absorbance was measured using a Spark control 10 microplate reader from TECAN and an Agilent Technologies, Cary 300 UV-Vis spectrophotometer enabling Peltier temperature control. MARCHEREY-NAGEL GmbH \& Co KG 60/40-63 mesh silica gel for Liquid Flash Chromatography and MARCHEREY-NAGEL GmbH \& Co KG 60 F254 silica gel TLC plates with anisaldehyde stain for detection were used. Reaction $\mathrm{pH}$ for preparative synthesis was maintained using a TitroLine ${ }^{\circledR} 7000$ autotitrator. NMR spectra were recorded in $\mathrm{D}_{2} \mathrm{O}$ or DMSO on a $400 \mathrm{MHz}$ Bruker Avance III HD spectrometer. Chemical shifts are referenced to the residual solvent peak. The following multiplicity abbreviations are used: (s) singlet, (d) doublet, (t) triplet, (m) multiplet.

In situ ${ }^{1}$ H NMR measurements. Progress of preparative scale enzymatic synthesis were monitored by using quantitative in situ ${ }^{1} \mathrm{HNMR}$ relative to 3-trimethylsilyl-2,2,3,3tetradeuteropropionate $\left(\mathrm{TSP}-\mathrm{d}_{4}\right)$ as internal standard. Aliquots of the reaction mixture were removed overtime $(450 \mu \mathrm{L})$ and mixed with $50 \mu \mathrm{L}$ of TSP- $\mathrm{d}_{4}\left(50 \mathrm{mM}\right.$ in $\left.\mathrm{D}_{2} \mathrm{O}\right)$.

Procedure of D-serine synthesis catalyzed by D-TA E3005 (CFE). To the solution containing glycine and formaldehyde $(50 \mathrm{mM}$ or $100 \mathrm{mM})$ were added PLP $(0.05 \mathrm{mM}), \mathrm{MgCl}_{2}(10 \mathrm{mM})$ and cell free extract of D-TA E3005 $(133 \mu \mathrm{L}$ of CFE containing $3.5 \mathrm{mg}$ of proteins $)$ in $\mathrm{H}_{2} \mathrm{O}$. The $\mathrm{pH}$ was adjusted at 7.3 with $0.1 \mathrm{M} \mathrm{NaOH}$. After $24 \mathrm{~h}$, methanol (twice the reaction mixture volume) was added. After $16 \mathrm{~h}$ at $4^{\circ} \mathrm{C}$, the solution was filtrated and evaporated under reduced pressure. D- 
serine was characterized by HPLC and ${ }^{1} \mathrm{H}$ NMR (SI) and was obtained as a white solid with 97\% yield.

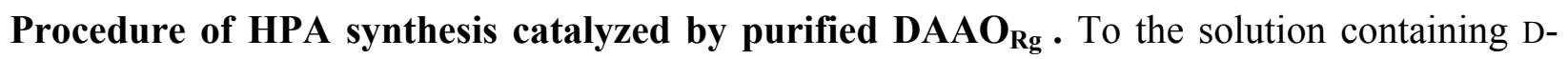
serine $(50 \mathrm{mM})$ previously produced using D-TA were added catalase (1 mg, i.e.1998U-4995 $\mathrm{U} / 2 \mathrm{~h})$ and $\mathrm{DAAO}_{\mathrm{Rg}}(2 \mathrm{mg}, 86 \mathrm{U})$ giving a final volume of $20 \mathrm{~mL}$. Oxygen was bubbled into the reactor $\left(10 \mathrm{~mL} \cdot \min ^{-1}\right.$ at atmospheric pressure $)$. The reaction mixture was stirred $(100 \mathrm{rpm})$ at $25^{\circ} \mathrm{C}$, and the $\mathrm{pH}$ was automatically maintained at 7 by adding $\mathrm{HCl}(0.1 \mathrm{M})$ using a $\mathrm{pH}$ stat. Oxygen was bubbled into the reactor $\left(10 \mathrm{~mL} \cdot \mathrm{min}^{-1}\right.$ at atmospheric pressure). The reaction was monitored by measuring HPA appearance using the LDH assay and D-serine consumption using the $\mathrm{DAAO}_{\mathrm{Rg}} \mathrm{LDH}$ assay. The completion of the reaction was evidenced by in situ ${ }^{1} \mathrm{H} \mathrm{NMR}$.

Procedure of simultaneous cascade synthesis catalyzed by purified $\mathrm{TK}_{\mathrm{gst}}$ and DAAO $\mathrm{Rg}_{\mathrm{Rg}}$ ThP $(0.1 \mathrm{mM}), \mathrm{MgCl}_{2}(1 \mathrm{mM})$, D-serine previously produced using D-TA $(50 \mathrm{mM})$ and acceptor aldehyde $(50 \mathrm{mM})$ were dissolved in $\mathrm{H}_{2} \mathrm{O}$ and the $\mathrm{pH}$ was adjusted to 7 with $0.1 \mathrm{M} \mathrm{NaOH}$. To this stirred solution were added catalase $(1 \mathrm{mg} / 2 \mathrm{~h}, 1998-4995 \mathrm{U} / 2 \mathrm{~h}), \mathrm{TK}_{\mathrm{gst}}(2 \mathrm{mg} / 2,7 \mathrm{~h}, 4,7 \mathrm{U} / 2,7 \mathrm{~h})$ and $\mathrm{DAAO}_{\mathrm{Rg}}(2 \mathrm{mg}, 86 \mathrm{U})$ giving a final volume of $20 \mathrm{~mL}$. Oxygen was bubbled into the reactor $\left(10 \mathrm{~mL} \cdot \mathrm{min}^{-1}\right.$ at atmospheric pressure $)$. The reaction mixture was stirred $(100 \mathrm{rpm})$ at $25^{\circ} \mathrm{C}$ and the $\mathrm{pH}$ was automatically maintained at 7 by adding $0.1 \mathrm{M} \mathrm{HCl}$ using a $\mathrm{pH}$ stat. Simultaneous cascade reactions were monitored by measuring D-serine and aldehydes consumption by in situ ${ }^{1} \mathrm{H}$ NMR and TLC. After total conversion of D-serine and/or aldehydes (8-32 hours), silica was added to the supernatant and the suspension was concentrated to dryness under reduced pressure before dry loading onto a flash silica column. Products $\mathbf{3}$ and $\mathbf{4}$ were isolated by silica gel chromatography using eluent $\mathrm{CH}_{3}-\mathrm{COO}\left(\mathrm{C}_{2} \mathrm{H}_{5}\right) / \mathrm{CH}_{3} \mathrm{OH}(9 / 1)$ and $\mathrm{CH}_{2} \mathrm{Cl}_{2} / \mathrm{CH}_{3} \mathrm{OH}(9: 1)$ respectively. 
(3S)-1, 3, 4-trihydroxy-butan-2-one 2 (L-erythrulose) 3. Compound 3 was isolated as a yellow oil; yield: $160 \mathrm{mg}(44 \%)$. $[\alpha]_{\mathrm{D}}{ }^{25}=+6.3\left(\mathrm{c} 1.48, \mathrm{H}_{2} \mathrm{O}\right)$, lit. $[\alpha]_{\mathrm{D}}{ }^{25}=+6.3\left(\mathrm{c} 1.1, \mathrm{H}_{2} \mathrm{O}\right),{ }^{28}[\alpha]_{\mathrm{D}}{ }^{25}=+6.7$ (c 1.48, $\left.\mathrm{H}_{2} \mathrm{O}\right) .{ }^{29} \mathrm{NMR}$ spectra were identical to those previously described. ${ }^{28}{ }^{1} \mathrm{H}$ NMR (400 MHz, MeOD): d=4.52 (d, J=19.3 Hz, 1H, 1-HA), 4.45 (d, J=19.3 Hz, 1H, 1-HB), 4.26 (t, J=4.2 Hz, 1H, 3-H), 3.80 (dd, J=11.6, 4.5 Hz, 1H, 4-H), 3.76 (dd, J=11.6, 4.0 Hz, 1H, 4-H); ${ }^{13} \mathrm{C}$ NMR (101 MHz, MeOD): $\mathrm{d}=212.98$ (C-2), 77.82 (C-3), 67.75 (C-1), 64.86 (C-4). m/z HRMS found [M+HCOO]165.0405, $\mathrm{C}_{5} \mathrm{H}_{9} \mathrm{O}_{6}$ requires 165.0396 .

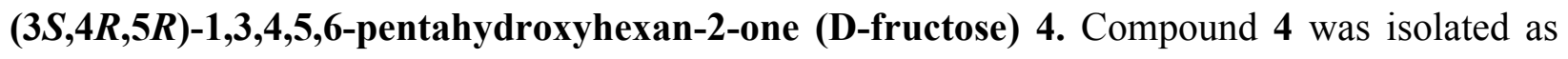
colorless oil (118 mg, 65\% yield). NMR data were identical to those previously described (ratio :73/22/5; lit. Ratio : 75/21/4). ${ }^{30,31}{ }^{1} \mathrm{H}$ NMR $\left(400 \mathrm{MHz}, \mathrm{D}_{2} \mathrm{O}\right): \delta$ (ppm) $\beta$-D-fructo-2,6pyranose 4.09-4.04 (m, 1H, H6a); 4.04-4.02 (m, 1H, H5); 3.93 (dd, $J=10.0 \mathrm{~Hz}, J=3.5 \mathrm{~Hz}, 1 \mathrm{H}, \mathrm{H} 4)$; 3.83 (d, $J=10.0 \mathrm{~Hz}, 1 \mathrm{H}, \mathrm{H} 3) ; 3.76-3.72$ (m, 2H, H6b, H1a); 3.60 (d, $J=11.7 \mathrm{~Hz}, 1 \mathrm{H}, \mathrm{H} 1 \mathrm{~b}), \beta-\mathrm{D}-$ fructo-2,5-furanose 4.17-4.13 (m, 2H, H3, H4); $3.84(\mathrm{~m}, 1 \mathrm{H}, \mathrm{H} 5) ; 3.83(\mathrm{~m}, 1 \mathrm{H}, \mathrm{H6a}) ; 3.69(\mathrm{~m}, 1 \mathrm{H}$, H6b); 3.63 (d, $J=12.1 \mathrm{~Hz}, 1 \mathrm{H}, \mathrm{H1a}) ; 3.58$ (d, $J=12.1 \mathrm{~Hz}, 1 \mathrm{H}, \mathrm{H} 1 \mathrm{~b}), \alpha$-D-fructo-2,5-furanose 4.174.13 (m, 2H, H3, H5); 4.05-4.01 (m, 1H, H4); 3.86-3.82 (m, 1H, H6a); 3.74-3.70 (m, 1H, H6b); 3.72-3.68 (m, 2H,H1a/b). ${ }^{13} \mathrm{C}$ NMR (101 MHz, $\mathrm{D}_{2} \mathrm{O}$ ): $\delta$ (ppm) $\beta$-D-fructo-2,6-pyranose 99.12 (C2); 70.72 (C4); 70.25 (C5); 68.61 (C3); 64.94 (C1); 64.42 (C6), $\beta$-D-fructo-2,5-furanose 102.54 (C2); 81.72 (C5); 76.44 (C3); 75.49 (C4); 63.74 (C1); 63.43 (C6), $\alpha$-D-fructo-2,5-furanose 105.49 (C2); 83.0 (C3); 82.37 (C5); 77.09 (C4); 63.96 (C1); 62.15 (C6). m/z HRMS found [M+Cl]215.0317, $\mathrm{C}_{6} \mathrm{H}_{12} \mathrm{O}_{6} \mathrm{Cl}$ requires 215.0321.

\section{ASSOCIATED CONTENT}

\section{Supporting Information.}


Production and activity determination of $\mathrm{DAAO}_{\mathrm{Rg}}$ and $\mathrm{TK}_{\mathrm{gst}},{ }^{1} \mathrm{H} \mathrm{NMR},{ }^{13} \mathrm{C} \mathrm{NMR}$ spectra of ketoses 3 and $\mathbf{4}$.

\author{
AUTHOR INFORMATION \\ Corresponding Authors \\ *Laurence.hecquet@uca.fr \\ * Juliette.martin@seqens.com \\ *Pascal.auffray@seqens.com \\ * Jerome.collin@seqens.com \\ ACKNOWLEDGMENTS
}

Funding Sources

This work was funded by the Fonds Régional Innovation Laboratoire (grant DOS00494484/00, to L.H.).

REFERENCES

1. a) M. Adamczak,.; K. H. Sajja, Food Technol. Biotechnol. 2004, 42, 251-264. b) R. K. Singh, M. K. Tiwari, R. Singh, J.-K. Lee, Int. J. Mol. Sci. 2013, 14,1232-1277.

2 R. N.Patel, Ed. Biocatalysis in the Paharmaceutical and Biotechnology Industries, CRC Press, 2010.

3 A. S. Wells,J. W. Wong, P. C. Michels, D. A. Entwistle, K. Fandrick, G. L. Finch, A. Goswami,H. Lee, S. Mix, T. S. Moody, L. Pang, R. K. Sato, N. J. Turner, T. J. Watson, Org. Process Res. Dev. 2016, 20, 594-601.

4 N. J. Turner E. O’Reilly Nat. Chem. Biol., 2013, 9, 285-288

5 R. A. Sheldon, J. M. Woodley Chem. Rev., 2018, 118, 801-838. 
6 J. H. SchrittwieSer, S. Velikogne, M. Hall W. Kroutil, Chem. Rev., 2018, 118, 270-348.

7 J. M. Sperl, V. Sieber, ACS Catal., 2018, 8, 2385-2396.

8 S. Wu, Z. Li, Chem CatChem, 2017, 10, 2164-2178.

9 a) Z. Li, Y. Gao, H. Nakanishi, X. Gao, L. Cai, J. Org Chem. 2013, 9, 2434-2445. b) K. Izumori, J. Biotechnol., 2006, 124, 717-722 ; c) L. Wen, K. Huang, M. Wei, J. Meisner, Y. Liu, K. Garner, L. Zang, X. Wang, X. Li, J. Fang, H. Zhang, P.G. Wang, Angew. Chem. Int. Ed. Engl., 2015, 54, 12654-12658

10 a) J. Li, J. Yang, Y. Men, Y. Zeng, Y. Zhu, C. Dong, Y. Sun, Y. Ma, Appl Microbiol. Biotechnol., 2015, 99, 7963-7972 ; b) S. M. Dean, W. A. Greenberg, C. H. Wong, Adv. Synth. Catal., 2007, 349, 1308-1320 ; c) P. Clapes, W.-D. Fessner, G. Sprenger, A. K. Samland, Curr. Opin. Chem. Biol., 2010, 14, 154-167 ; c) A. Li, L. Cai, Z. Chen, M. Wang, N. Wang, H. Nakanishi, X. D. Gao, Z. Li, Carbohydr. Res., 2017, 452, 108-115.

11 a) Y. Kobori, D. C. Myles, G. M. Whitesides, J. Org. Chem., 1992, 57,5899-5907. b) T. Ziegler, A. Straub, F. Effenberger, Angew. Chem. Int. Ed. Engl., 1988, 100, 737-738. c) L. Hecquet, J. Bolte, C. Demuynck, Tetrahedron, 1996, 52, 8223-8232. d) F. T. Zimmermann, A. Schneider, U. Schörken, G. A. Sprenger, W.-D. Fessner, 1999, 10, 1643-1646. e) N. J. Turner, Curr. Opin. Biotechnol., 2000, 11, 527-531 f) F. Charmantray, V. Helaine, B. Legeret, L. Hecquet, J. Mol. Catal. B: Enzym., 2009, 57, 6-9.

12 F. Dickens, D. H. Williamson. Biochem. J. 1958, 68, 74-81.

13 J. Abdoul Zabar, I. Sorel, V. Hélaine, F. Charmantray, T. Devamani, D. Yi V. de Berardinis, D. Louis, P., Marlière, W.D. Fessner, L. Hecquet, Adv. Synth. Catal., 2013, 355, 116-128.

14 a) L. Hecquet, J. Bolte and C. Demuynck. Enzymatic. Tetrahedron, 1996, 52, 8223-823. b) M. Lorillière, M. De Sousa, F. Bruna, E. Heuson, F. Gefflaut, V de Berardinis, T. Saravanan, D. Yi, W.-D. Fessner, F. Charmantray, L. Hecquet, Green Chem., 2017, 19, 425-435. c) F. Subrizi, M. Cárdenas-Fernández, G. J. Lye, J. M. Ward, P. A. Dalby, T. D. Sheppard, H. C. Hailes, Green Chem., 2016, 18, 3158-3165. d) M. Bawn, F. Subrizi, G. J. Lye, T. D. Sheppard, H. C. Hailes, J. M. Ward. Enzyme Microb. Technol., 2018, 116, 16-22.

15 M. L'enfant, F. Bruna, M. Lorillière, N. Ocal, W.-D. Fessner, L. Pollegioni, F. Charmantray, L. Hecquet. Adv. Synth. .Catal., 2019, 361, 2550-2558.

16 a) L. Pollegioni, A. Falbo, M. S. Pilone, Biochim. Biophys.Acta, 1992, 120, 1-16. b) S. Fantinato, L. Pollegioni., S. M. Pilone, Enz. Microb. Technol., 2001, 29, 407-412. 
17 K. Jung, M. Seifert, T. Herrling, J. Fuchs, Spectrochim. Acta A Mol Biomol. Spectrosc., 2008, 69, 1423-1428.

18 H. D. Belitz, W. Grosch, P. Schieberle, in Food Chemistry, 2009, 248-270, "Hiedelber": Springer-Verlag.

19 Protéus by Seqens has a collection of $>300$ off-the-shelf enzymes

20 H. Charmolue, R. W. Rousseau, AIChE Journal, 1991, 37, 1121-1128

21 H. Ikeda, Y. Yonetani, S. I. Hashimoto, Process for producing D-serine, US 7,186,532 B2, Kyowa Hakko Kogyo Co Ltd.

22 a) L.Pollegioni, G. Molla, S.Sacchi, E. Rosini, R. Verga, M. S. Pilone, Appl. Microbiol. Biotechnol., 2008, 78, 1-16 ; b) L. Pollegioni, P. Motta, G. Molla, Appl. Micr. Biotech., 2013, 97, 9323-9341.

23 a) L.Pollegioni, G. Molla, S.Sacchi, E. Rosini, R. Verga, M. S. Pilone, Appl. Microbiol. Biotechnol. 2008, 78, 1-16 ; b) L. Pollegioni, P. Motta, G. Molla, Appl. Micr. Biotech. 2013, 97, 9323-9341. b) L. Pollegioni, K. Diederichs, G. Molla, S. Umhau, W. Welte, S. Ghisla, M. S. Pilone, J. Mol. Biol. 2002, 324, 535-546. c) L Pollegioni, S Iametti, D Fessas, L Caldinelli, L Piubelli, A Barbiroli, M.S. Pilone, F. Bonomi, Protein Sci. 2003, 12, 10181029.

24 G. Ali, T. Moreau, C. Forano, C. Mousty, V. Prevot, F. Charmantray, L. Hecquet, ChemCatChem, 2015, 7, 3163-3170

25 a) J. Abdoul Zabar, M. Lorillière, D. Yi, L. Nauton, F. Charmantray, V. Hélaine, W.-D. Fessner, L. Hecquet, Adv. Syn. Catal. 2015, 357, 1715-1720 ;. b) D. Yi, T. Saravanan, T. Devamani, F. Charmantray, L. Hecquet and W.-D. Fessner, Chem. Commun. 2015, 51, 480483; c) M. Lorillière, M. De Sousa, F. Bruna, E. Heuson, T. Gefflaut, V. de Berardinis, T. Saravanan, D. Yi, W.-D. Fessner, F. Charmantray, L. Hecquet, Green Chem. 2017, 19, 425 - 435 ; d) T. Saravanan, S. Junker, M. Kickstein, J. Hegen, S. Hein, M. K. Link, S. Witt, M. Lorillière, L. Hecquet, W.-D. Fessner, Angew. Chem. Int. Ed., 2017, 56, 5358-5362. e) M. Lorillière, R. Dumoulin, M.L'Enfant, A. Rambourdin, V; Thery, L. Nauton, W.-D. Fessner, F. Charmantray, L. Hecquet, ACS Catalysis, 2019, 9, 4754-4763.

26 U.K. Laemmli, Nature, 1970, 227, 680-685.

27 L. Hecquet, J. Bolte, and C. Demuynck, Biosci. Biotech. Biochem., 1993, 57 , 2174-2176. 
28 K. Benaissi, V. Hélaine, V. Prévot, C. Forano, L. Hecquet, Adv. Syn. Catal., 2011, 353, 1497-1509.

29 M. E. B. Smith, E. G Hibbert, A. B. Jones, P. A. Dalby, H. C. Hailes, Adv. Syn. Catal. 2008, $350,2631-2638$.

30 W. Funcke, Carbohydr. Res. 1979, 75, 305-309.

31 T. Barclay, M. Ginic-Markovic, M. R. Johnston, P. Cooper and N. Petrovsky, Carbohydr. Res. 2012, 347, 136-141. 